\title{
On the Influence of Chinese Culture on Ezra Pound
}

\author{
Yang Zhao
}

Foreign Languages College, Beihua University, Jilin 132013, China.

\author{
Keywords: Pound, Chinese culture, influence
}

\begin{abstract}
As a well-known modern poet and outstanding critic and translator, Pound is praised as the leading authority in American contemporary poetic circles, and he is also an acknowledged leader for the Imagistic Verse of American Literature. It is believed that Pound is a poet with love for Chinese culture. He translated and published an enormous variety of Chinese classical poems, bringing the Chinese traditional poetry into the western modern culture, hence stimulating the development of American New Verse Movement. Many of his poems are the recreation of some Chinese classical verses based on translation. Thus, this paper explains in detail that Pound had adopted a lot from ancient Chinese culture in many aspects, including the Chinese painting techniques, Chinese ancient poetry, Chinese characters, and especially the philosophy of Confucius. In addition, this paper analyses the reasons that Chinese culture has great influence on Ezra Pound.
\end{abstract}

\section{Introduction}

Ezra Pound, a pioneer of Imagistic Verse of American Literature, is a poet with love for Chinese culture. He works with perseverance in his life to study Chinese culture and propagates it to the West through his translation and writing. In other words, Pound's great success most benefits from Chinese culture. What is more, "Pound and China" has become one of major subjects in the history of cultural exchange in China and the West. Therefore, a systematic analysis of the influence of Chinese culture on Pound is very beneficial to propel further development of the research of Pound.

\section{The reasons for Pound's interested in Chinese culture}

In western cultural tradition, when the paradise lost happiness, people will go to seek salvation so as to come back the Garden of Eden once again. In Pound's eyes, life was sordid personal crushing oppression, and culture produced nothing but "intangible bondage." As a result, anxious to stem the tottering Western civilization from going under, and to find a rudder for the rudderless American people, Pound ransacked history for the ideals and principles long buried and lost in the golden past. When he looked about and turned east, he found a Messiah in Confucius and the medicine for the disease of the West in his time. Confucius, Pound believed, can enlighten and civilize the barbarous Occident. Thus, Pound was, for the most part of his life, trying to offer Confucian philosophy as the one faith that he felt could help to save the West.

\section{Pound's reference to the ancient Chinese painting}

Pound had come into contact with Chinese art in his youth. There were some ancient Chinese arts in his family, and he also came across a number of ancient Chinese sculptures and paintings when he was in the University of Pennsylvania. However, it is Laurence Binyon's lecture on the ancient Chinese painting that really made him begin to understand the essence of Chinese painting and benefit from it. Laurence Binyon was an expert of the British Museum. In the early $20^{\text {th }}$ century, he held a series of lectures to introduce ancient Chinese paintings in detail, and he also displayed a number of ancient Chinese paintings in these lectures.

Ancient Chinese painting stresses quite similar and freehand brushwork and it also pays attention to the mood of the rendering. In the painting techniques, dot painting, splash-ink, sketch and even boneless painting are commonly used. In the composition, people always emphasize using background to foil the subject. Pound learned a lot from these painting techniques and aesthetic 
principles, and later he applied them into his poetry, especially in his short poem "In a Station of the Metro". When he recalled how to create this poem, Pound had emphasized that what he found at that time was not to trace vocabulary, but "a number of small dots of paint". These so-called "spots" in Chinese painting is called "dot painting", a commonly used painting technique, which is used to constitute the petals, leaves, and even the mountains or trees texture. And his verse "Petals on a wet, black bough" is just the reproduction of the wet squid in Chinese painting. Obviously, he imitated our ancient Chinese painting technique, which draw pictures only used ink as the pigment.

In addition, we can appreciate the impact of Chinese painting on Pound's aesthetics, especially the way to handle space, composition and color. Chinese painting stresses a balanced composition, and often foils atmosphere by leaving over large areas of white space and changing the shade of colors. In the poem of "In a Station of the Metro", Pound juxtaposed two images together --- one is the faces of a few pretty women and their children at the station, the other is the petals on a wet, black bough, making the latter become the image of former. Station and the other people at the station had become a blank; only the faces of those women and children were just as the petals in a slanting and stretching bough. Its beauty can only realize, but unspeakable. Chinese ancient paintings pay attention to the artistic conception, and artistic conception is completed through the typical imagery and clever composition. In Pound's view, the essence of poetry is imagery, but imagery is not a mathematical equation. Indeed, it is the stuff which relates to form and mood. From these discourses, it is not difficult to see that Pound learns many aesthetic thoughts from ancient Chinese painters.

\section{Pound's reference to the Chinese characters}

Pound has always been in love with Chinese characters. However, that he really began to study the characters seriously was from collating the notes of Sino-Japanese cultural studies which written by Ernest Fenollosa. By reading his researching manuscripts and notes, Pound recognized that an ideographic Chinese character often consisted of several ideographic parts, and several parts of itself are a very good symbol of poetry. Therefore, he believes that "a Chinese character is often a special image," while the combination of characters can often get an effect of animation." In other words, Chinese characters are not simply realistic graphics; each character can be regarded as an ideographic picture, especially those characters with space structure. They are novelty in Pound's eyes, because its pictographic is like a wonderful poem. Therefore, Chinese character in Pound's eyes is not a word but a concise poem.

In short, in Pound's eyes, Chinese character is a poetic language, and it presents the aesthetic principles of composition of poetry everywhere. In poetry, characters are considered as the ideal medium of poetry by Pound.

Inspired by the poetic and picturesque characters, Pound formed his poetic theory of vortex and established his own unique way for writing _ ideographical method. He summed up his ideographical method with three words, that is, phanopoeia, melopoeia, logopoeia. Thanks to these three ways of writing, Pound not only achieved the beauty of form and sound, but also enriched the meaning of poetry in his writing, which made the traditional English poetry enter a new era.

Phanopoeia was coined by Pound himself and consisted of two roots. Pound's explanation of this word is "casting the object into the visual imagination", because he felt "natural object is always the perfect symbol". He and other Imagist poets laid down three poetic principles, the first one is the "direct treatment of the thing, whether subjective or objective." The purpose of this principle is to ask poets to express poetry visually, like Chinese characters, so that people can understand its meaning easily.

If phanopoeia is Pound's way to achieve the beauty of form, then melopoeia is his way to achieve the beauty of sound. Melopoeia is also a fit word. Melo means songs, so the meaning of melopoeia is to create with songs. Pound thought poetry is an art between music and painting. The artistic effect of poetry should be achieved in two ways: one is vision, which is the clear picture; the other is hearing, which refers to wonderful sound. Therefore, Pound and other Imagist poets put forward that the 
rhythm of poetry should be composed in the sequence of the musical phrase, not in the sequence of a metronome.

Logopoeia is Pound's third way of writing. Logopoeia is also a fit word, which was formed by "logo" and "poeia". The original meaning of logo is shape or form, and logopoeia represents the physical creation. In fact, this word can embody a distinctive poetic form of Pound, which is non-coherent fragment of text. This poetic form is similar to Chinese fit characters, and Pound referred to this structure as the vortex. Vortex is essentially a new combined synthesis based on the Imagery. Therefore, Pound thought, the form of poetry is an overlay, or an intersection of one point with another point. Some scholars had ever named this kind of structure as ideographic structure.

\section{Pound's reference to ancient Chinese poetry}

Chinese classical poetry's strict meter and Chinese's special syntax create the omission of syntax tag, using the splicing of images, creating a high degree of conciseness and concentration in a poem. Influenced by this point, Pound advocated writing short poems. He believes that poetry does not need to write too long, but each poem must give people deep impression. Therefore, his own poems are often essays with only a few lines, or the odes with 10 lines more or less, for example, In a Station of the Metro, and Pound himself had said that this poem is under the influence of Chinese poetry.

By studying Chinese poetry unremittingly, Pound excitedly claimed that he found "the highest achievement of art of poetry" in Chinese poetry. In my opinion, what Pound said referred to "disembodiment", "superposition" and other expressive techniques and skills that he had learned from Chinese classical poetry.

Disembodiment refers to the phenomenon of disintegration of syntax in the poetry. When Pound translated "Liu Che" and other classical poetry, he imitated the syntax of Chinese original poem intentionally and omitted part of articles, prepositions and linking verbs. Consequently, the translation can retain the ambiguity and flexibility of interpretation. In addition, Pound applied such unique skill into his own poetry, such as "Rain; empty river; a voyageur."

Superposition is another typical feature of Chinese poetry, but this term was created by Pound. Pound had ever said: "This imagist poetry is a form of image overlay, namely it is a kind of thinking on the other thinking." In Pound's later masterpiece "Cantos", superposition is more complicated; juxtaposition, superposition and omission are used more commonly.

For example, Pound translated Liu Che's poem as following:

The rustling of the silk is discontinued,

Dust drifts over the courtyard,

There is no sound of footballs, and the leaves

Scurry into heaps and lie still,

And she the rejoicer of the heart is beneath them:

A wet leaf that clings to the threshold.

Here, Pound deleted the last two sentences, and then the fourth sentence had naturally become a "superimposed image". He omitted the linking verb between the body and metaphorical body, using a specific image to compare another specific image. Thus it can be seen, Pound showed his great ingenuity in selecting imagery.

\section{Pound's reference to the Confucian culture}

In Chinese culture, what Pound had learned most should be Confucianism. Because of respecting Confucianism, Pound translated a series of Confucian classics so that he had a deeper understanding of Confucianism and that also had great impact on his later creation. On the whole, Pound's reference on Confucianism can be roughly divided into the following areas.

Confucius had always stressed the importance of the social order. In his view, social order first came from individual's self-cultivation. As individuals, we should learn how to be a good man firstly, that is, self-cultivation. Only after the completion of self-cultivation, average people are able to make 
their families well-organized; only completed the self-cultivation, the monarch can govern his own country safely. However, the most fundamental principles of self-cultivation are order and benevolent heart. Only everyone abides by the order, the society will be safe; only everyone has benevolent heart, the society will be in harmony.

Pound agreed with Confucian's ideas about self-cultivation and social order. Chapter 13 of Cantos shines with the light of the Confucian ideal of harmony and order.

If a man have not order within him,

He can not spread order about him;

And if a man have not order within him,

His family will not act with due order;

And if the prince have not order within him,

He can not put order in his dominions.

Besides, from Chapter 85 until the end, Pound praised Confucius' benevolent ideas from different perspectives in Cantos. As it were, Pound regarded Confucianism as a good medicine to treat the chaotic spiritual world of modern western society.

Another reason for Pound interested in Confucianism is that Pound takes it as religion, more precisely, he thought of Confucianism as an antidote of Christian, because there was no effective cure in Christianity for the disease of his times. To him official Christianity was a sink, and the Bible was poison which had been instilled for centuries into helpless babies. However, Confucianism and Christianity are as different as chalk from cheese, because Confucianism underlines the importance of getting into society. It tells people to put the most important goal in real life. It also advocated cultivating an ego based on natural instincts, rather than an obedient Christian. What is more, Confucian emphasis on social responsibility and cooperation between individuals. Pound believes that if there is a paradise in this world, it should also be on earth. Human's obligation is not to accept wisdom passively, but to get into society actively as Confucius, creating order and balance with great enthusiasm in the world.

Pound also praised highly of Confucian thought of education, so he applied a lot in his poetry. The core of Confucian education thinking is human nature, and Pound fully agreed to this point. Pound was very dissatisfied with the Western education system, because he thought the education system had suppressed personality and humanity, and they also made people forget the tradition. The reason for he interested in the education thought of Confucius was that Confucius stresses developing students' intelligence and moral sense on the basis of their personality and instinct. Pound believed that Confucian education thinking was a good one. It is no wonder that such good education thinking would play a vital role in keeping the health of a nation's culture and ethic. Chapter 13 of Cantos is a commendation of Confucian teaching methods and the lashing of western fickleness in modern life.

\section{Summary}

Pound learned a lot from Chinese culture; meanwhile, he applied them into his writing. Therefore, we can always find traces of Chinese culture in his poetry. As a result, Chinese culture is well known in the West because of Pound's works. On the basis of the above discussion, we may come to the conclusion that Chinese culture has great influence on Ezra Pound and has always plays a leading role in his life. On one hand, Pound learned a great deal of knowledge from Chinese culture, especially from Chinese painting, Chinese characters, poetry and philosophy of Confucius, then he cited and applied them into his writing and translation. On the other hand, as a lover of Chinese culture, Pound had played a positive role in spreading Chinese culture to the West, and launched influential "Chinese fever" during the campaign of Anglo-American new poetry. In addition, Pound's experience of studying Chinese poetry and developing skills of Chinese poetry in writing can inspire us, and it will be good reference for us to study classical Chinese poetry and disseminate our brilliant culture. At the same time, we can realize with pride that it is really Chinese culture that makes Pound have great success and expand his widespread influence in the East and West. When we understand this point 
and even make some researches, we will look at our cultural tradition from a new perspective and learn how to get nutrition from them so as to carry forward our Chinese culture.

\section{References}

[1] Carpenter, Humphrey, A Serious Character: The Life of Ezra Pound, Houghton Mifflin, 1988.

[2] Grieve, Thomas F. , Ezra Pound's Early Poetry and Poetics, University of Missouri Press,1997.

[3] Rubinstein, Annette T., American Literature Root and Flower, Foreign Language Teaching and Research Press, 1998.

[4] Li Zhengshuan, Chen Yan, American Poetry Research, Peking University Press, 2007.

[5] Shen Fuying, On Pound's Poetic Creation of Chinese Culture, Qilu Journal. (2005)51-53. 